ARTICLES AND SKETCHES

STUDIA NORWIDIANA 38:2020

ENGLISH VERSION

DOI: http://dx.doi.org/10.18290/sn.2020.38-8en

MAGDALENA KOWALSKA

\title{
THE COLUMN IN PLACE VENDÔME AND THE FLEETING FORM OF ANCIENT ROME IN THE WRITINGS OF CYPRIAN NORWID
}

\section{THE THEME AND THE RESEARCH QUESTION CONCERNING IT}

In the 1948 book Cyprian Norwid: poeta i sztukmistrz Kazimierz Wyka argues that the column is "one of Norwid's two favourite elements of classical architecture." This article examines its two literary representations showcasing this predilection: the Roman columns of Trajan and Marcus Aurelius, and most importantly - the Vendôme Column in Paris. ${ }^{2}$ These monuments share one fundamental feature, namely the fact of being triumphal columns. Out of the many meanings associated with the word "column" - pillar, statue, vertical support of a building's part, which can also serve as the base of a statue or monument - one should choose those that are synonyms of statue in order to grasp the functions performed by this element of urban architecture. A poetic description of a triumphal column constitutes a different kind of image than representations of colonnades, which emphasise the plurality of columns and sometimes their positioning on the plan of the building, as encountered for example in the preface to Quidam: "do tego kościoła, co w kwadracie kolumn świątyni starożytnej jako gołąb w rozłamanej klatce przestawa," or in the phrase "dalej kolumn

${ }^{1}$ K. WYKA, Cyprian Norwid: poeta i sztukmistrz, Kraków 1948, p. 100.

${ }^{2}$ This article uses the term Vendôme Column, although it is imprecise since it has been called the Austerlitz Column, the Column of Victory, or the Column of the Great Army. Cf. A. TARDIEU, La Colonne de la Grande Armée d'Austerlitz ou de la Victoire, monument triomphal érigé en bronze sur la Place Vendôme de Paris, Paris 1822, p. 12. However, the name "la colonne Vendôme" is in fact used in the French language. 
rząd" [further away a row of columns] from the poem Z listu (do Wtodzimierza Łubieńskiego) [From a Letter (to Włodzimierz Eubieński)]. Terms like "klatka" [cage] and "rząd" [row] bring to mind regular spaces between columns. Still, the opposition between multiplicity and singularity does not exhaust the aspect that differentiates the message of the triumphal column from that of different column types because the kind of image that is represented by the triumphal column requires different interpretative tools than the ones necessary to analyse a poetic rendition of a single column. Usually Norwid introduces just one column, the lone survivor out of many, as a result of which it becomes much like a triumphal column due to its singularity. However, unlike in the case of such monuments, a single one rather emphasises the absence of others ("greckiej kolumny, / $\mathrm{Na}$ brzegu morskim oszklonej - tak żal mi!") or accentuates the random positioning of the lone witnesses to former glory, e.g. in Quidam: "w przypowieści tej mojej, [...] lubo nie ma arków połamanych i rozrzuconych kolumn, nie mniej smętny, [...] krajobraz ruin się przedstawia."

The question that has accompanied me in analyses of Norwid's writings is posed here on the basis of an assumption derived from Hegel's lectures on aesthetics, which were recorded in a notebook belonging to Victor Cousin - one of several that circulated in Europe at the time. Introducing the aims of classical architecture, Hegel claimed it was necessary for a temple to be a space enclosed in three dimensions. ${ }^{3} \mathrm{He}$ also noted that pyramids, for example, are attractive because their length and width persuade us that the pyramid is in fact able to lift (porter) that which is at the top, while its peak is not meant to support anything, being itself supported - this is why the construction rises to form one point - the summit. The function of that which surrounds the peak is to lift that which is at the top, thus establishing a connection with the vicinity. The structure should make this double goal clear. It is in this context that there appears the question about the column that I have found inspiring: "L'abstraction du porter pour soi

${ }^{3}$ G.W.F. Hegel, Esthétique: cahier de notes inédit de Victor Cousin, ed. A.P. Olivier, Paris 2005, pp. 107-108: "Le but est que le temple doit être un enclos, une enveloppe." Further, he analyses the "forme de cet enclos": "1) Nous avons un endroit fermé dans les trois dimensions. La muraille enveloppe du côté de la langueur et de la largeur, mais pour la hauteur, le toit peut être horizontal ou oblique. [...] Une pyramide qui va en pointe nous plaît; car si nous voyons une largeur, nous sentons qu'elle est capable de porter; mais si une construction est bâtie dans le sens de la hauteur, la partie supérieure n'a plus la destination de porter. [...] La partie supérieure ne doit qu'être portée; elle doit montrer par sa forme même de ne plus pouvoir porter, c'est-à-dire: elle doit terminer en pointe. 2) Le but est d'entourer; ce but se partage en plusieurs déterminations: porter ce qui est en haut, et joindre ce qui sert à porter et à entourer. Une construction doit montrer chacune de ces deux déterminations dans leur abstraction pour soi. L'abstraction du porter pour soi est la colonne." 
est la colonne." The idea of that which supports itself (or lifts itself) is the column. In order to support the weight of a building, many columns are required, while in order to unify what surrounds it, it is necessary to connect them. However, a column as such is the idea of that which announces only itself. Returning to Norwid, let us recall one passage from Epimenides: "Kolumn wiele, [...] Zbłąkanych kolumn wiele, gmachu gdzieś szukało - " [Many columns, [...] Many lost columns were looking for an edifice] (DW III, 87). Therefore, paraphrasing the poet's words, I wish to ask what the column seeks if it is not a part of an edifice, as in the case of triumphal columns. What do they lift? What do they support? What are they the base for? I seek answers to these questions in the symbolic dimension because in reality this seems clear - these are monuments, which have often been changed in the course of history, extolling leaders, apostles as well as ruling dynasties.

\section{"TOUT HÉROS, TOUT GRAND HOMME A CHANGÉ DE PAYS; ROME N'EST PLUS DANS ROME, ELLE EST TOUTE À PARIS" - SOURCES OF INSPIRATION FOR CONSIDERING PARIS AS THE NEW ROME}

The theme of the column can be successfully interpreted in Norwid's works by recalling, as Wyka does, examples from antiquity, additionally analysing the symbolism of light in the vicinity of the column, or the relationship between the image of the column and the space of the temple. The choice of nineteenthcentury columns - ones contemporary to Norwid - as the subject of study would not be obvious if it had not been for several unquestionable facts that indicate the significance of the specific Parisian monument - the Vendôme Column. In biographical terms, the interpretation of the core of the discussed issue requires that we recall Norwid's protest against demolishing the column:

Jako członek Towarzystwa Artys[tów] Franc[uskich], kiedy zakładałem protestację przeciw zburzeniu Kolumny Vendôme i kościołów, wypowiedziałem wyraźnie, że zamiast znieważać kapłanów na ulicach i domy Boże plądrować, trzeba OŚWIECAĆ LUD, „car il vous détruira tous les monuments et tous les musées à l'exception de celui de l'Histoire Naturelle" (les singes comprendront les singes). [...] Wtedy pisać nie mogłem więcej nad znak pobieżny, z powodu że gdyby tylko była [1.] moja protestacja przeciw więzieniu duchowieństwa i burzeniu kościołów - 2. druga, przeciw obaleniu Kolumny Vendôme i 3. proklamacja do rodaków, aby odmówili służb Komunie i tej generacji (po czym dziennik „Temps” był zamknięty), to już trzy [...]. (PWsz IX, 483-484)

${ }^{4}$ D. Rowell, Paris: The "New Rome” of Napoleon I, London-New York 2012, Appendix 1. 
[As member of the Society of French Artists, when I was protesting against demolishing the Vendôme Column and churches, that instead of insulting priests in the streets and plundering temples we should be ENLIGHTENING THE PEOPLE, "car il vous détruira tous les monuments et tous les musées à l'exception de celui de l'Histoire Naturelle" (les singes comprendront les singes). [...] At that time, I could not write more because it would make three protests altogether: [1.] against imprisoning the clergy and demolishing churches, 2. against demolishing the Vendôme Column, and 3. proclamation to my compatriots to refuse to serve the Commune and its generation (the daily Temps was already closed) [...].

Norwid mentions the Vendôme Column several times, usually juxtaposing it with architectural elements from ancient Rome. While seeking possible answers about the roots of such comparisons it should be noted that Piotr Chlebowski rightly points to the work by Constantin François Volney as the source of analogies between ancient Rome and nineteenth-century France. ${ }^{5}$ Such comparisons were widespread at the time, although the very idea of translatio imperii is much older. It was already circulated in the Middle Ages thanks to Chrétien de Troyes, who argues in the novel Cligès (probably written in 1176) that the glory of knights (chevalerie) and clergy (clergie) was first transplanted from Greece to Rome, and then to France. ${ }^{6}$ This idea was echoed by many mediaeval French chroniclers, including Guillaume de Nangis, who held that both sapientia and militia travelled from Greece to Paris in order to form the third element - fides. ${ }^{7}$

The idea of translatio imperii was also expressed in plans to adapt the Vendôme Column as the plinth of a monument to Charlemagne. ${ }^{8}$ What would be achieved by referring to this topos? Its fundamental element is the concept of the empire. Thus, as Rebecca Comay notes, proponents of this idea would seek to provide a genealogy to conquered territories, extending a temporal dimension over

5 See: N.M. Alvey, Strange Truths in Undiscovered Lands: Shelley's Poetic Development and Romantic Geography, Toronto 2009, p. 34: "Volney's review of world history reflects the old concept of the translatio imperii, which was revived as the idea of progress in the eighteenth century. [...] A universal revolution starts in France, and Volney hopes that it will spread all over the world." D. SKILTON, "Tourists at the Ruins of London. The Metropolis and the Struggle for Empire," Cercles 17 (2007), p. 105: "Volney's project is to convince legislators that reason can produce ideal schemes of government which will enable states and empires to avoid the errors of the past, among them superstition and religious belief general, and so endure indefinitely, and in the 'Avertissement' to Les Ruines he refers directly to the Revolution as providing the legislator able to put such a programme into effect."

${ }^{6}$ Ch. DE Troyes, Cligès, Berlin 2006, p. 26.

${ }^{7}$ J.W. BALDwIN, Masters at Paris from 1179 to 1215, [in:] Renaissance and Renewal in the Twelfth Century, eds. R.L. Benson, G. Constable, C.D. Lanham, Toronto 1991, pp. 162-163.

${ }^{8}$ D. Rowell, Paris: The "New Rome" of Napoleon I, p. 70. 
spatial expansion. ${ }^{9}$ An empire cannot be destroyed and it never dies - it is only its centre and overall shape that are subject to shifts and transformations. Those who co-create a new empire wish to acquire the splendour of their predecessors in order to step into their honourable role of expansionists. ${ }^{10}$ Napoleon wanted to move the Trajan column to Paris and was convinced otherwise only by the argument that this would in fact destroy the monument. This fact is worth remembering when analysing Norwid's words about the Parisian "copy" of the Roman column.

In Norwid's poems, the Vendôme Column is revealed three times in the light of classical Roman culture: in the lyric "Vendôme," where Julius Caesar meets, on a Parisian night, with "Cezar drugi świata po-rzymskiego" [The second Caesar of the post-Roman world], i.e. Napoleon; in Odpowiedź do Włoch... (Fraszka) [Response to Italy... (An Epigram)], where one proper name refers to two things - as it turns out, there is Rome and "this Rome," i.e. Paris, where the exact same Trajan's column stands, only being "przebrązowana, na Napoleona wielkie imię" [re-bronzed to glorify Napoleon's great name]. In these testimonies of his interest in the column, one can discern signs of cultivating the Roman heritage in modern France. Finally, the said column appears in Listy [Letters] from the long poem Szczesna, where the cities of Paris and Rome are not identical or even spoken of as similar, but presented next to each other as subsequent points in the protagonist's itinerary, shedding light on each other and - as I wish to show - featuring elements of the column theme in descriptions, although only one actual column makes an appearance there - the one from Place Vendôme.

\section{SCENE ONE. "L'ÉPOQUE DE GLOIRE" OR "TOUS CES FANTÔMES DE GLOIRE" ?}

The words of Napoleon from the poem "Vendôme" may suggest that its message somehow explains the nature of the column, but they appear only mid-way

9 R. Comay, Mourning Sickness: Hegel and the French Revolution. Cultural Memory in the Present, Stanford 2010, p. 15: "The medieval ideology of translatio imperii had inextricably connected genealogical transmission to geographical conquest, temporal extension to spatial expansion: empire is defined as the uninterrupted relay of dynastic legitimacy and authority, without leakage or loss of symbolic potency, across territorial lines."

${ }^{10}$ D. Battles, The Medieval Tradition of Thebes: History and Narrative in the "Roman de Thèbes, Boccaccio, Chaucer, and Lydgate, London 2004, p. 23: "In a nutshell, translatio imperii bespeaks a desire to share in the authority of the ancients while replacing them."

11 T. Labourieu, La Colonne Vendôme, roman historique, Paris 1872, p. 3.

${ }^{12}$ V. Hugo, “À la colonne,” [in:] IdEM, Euvres complètes. Poésie, Paris 1834, p. 334. 
through the poem, suggesting the helplessness of the speaking persona with regard to the poem's audience:

ale komuż kazać mam o sile

Tryumfalnymi mierzonej kolumny?... ${ }^{13}$

[but who can I preach to about the power

of the column measured in triumphs?...]

We deal here with one column only - the Parisian one - although Julius Caesar is placed on the same level of imagery as the French Emperor. However, he reached this place - the one to which Napoleon was elevated on the column - as a result of a different kind of movement:

Cień Julijusza, w złotawej klamidzie,

Jakoby chmura popod księżyc idzie,

By śmiertelnemu, co pogląda z ziemi,

Wydał się światła-szyby rozlanemi,

I u kolumny zawisnąwszy szczytu $[\ldots] .^{14}$

[The shadow of Julius, in a golden coat

Going under the moon like a cloud,

Appearing to the mortal looking from below

Like light spilled on glass

Suspended at the top of the column]

The question of diminishing the differences between speakers has been emphasised by scholars. Anna Kadyjewska noted that Julius Caesar and Napoleon meet halfway and are harmonized by "volatile spirits and bronze weight." ${ }^{15}$ A similar metaphor also appears in an article by Jacek Lyszczyna, who underscores that "the protagonists in this unusual scene, who meet halfway between heaven and earth, are themselves en route, so to speak." ${ }^{, 16}$ However, it is impossible to disregard

${ }^{13}$ C. Norwid, Vendôme, PWsz I, 110.

${ }^{14}$ Ibid., p. 108.

${ }^{15}$ A. KadyjewsKa, Norwidowskie rozmowy umarlych - dialog postaci i epok, [in:] Liryka Cypriana Norwida, ed. P. Chlebowski, Toruń-Lublin 2003, p. 289.

16 J. Lyszczyna, Dumanie na placu Vendôme. Norwid wobec romantycznego kultu Napoleona, [in:] Norwid - spotkania kultur, ed. E. Chlebowska, Lublin 2015, p. 307. Elsewhere in this article the author concludes that the dialogue "is set by the poet not in the Elysian Fields, but in the sky's expanse," which supposedly decides about the "Christian character of the entire vision, including the contents of the dialogue conducted above" (ibid.). I am more convinced by the phrase "between heaven and earth," which is why I quote it in the article. One sign of connecting with 
significant differences between these figures, which are rooted primarily in their relation to stability or dynamism, and secondarily - in their point of departure.

What draws attention in the poetic metaphor at the poem's beginning is the play of light, but it is no less important that the verb is in the present tense, defining the actions of Julius Caesar through the passing of clouds, which indicate the process of walking ("idzie") and its conclusion: "zawisnął" [he hung]. The movement of the Moon around the Earth, or its revolution on its own axis are invisible to the naked eye. Consequently, it appears to be a static element of the night sky to "the mortal" and passers-by, in contrast to clouds hurried by the wind - a commonplace and easily observable phenomenon. Thus, Julius Caesar is a moving figure before he stops, apparently motionless (as if something tied him to the sky ${ }^{17}$ ), while Napoleon is held at this height by a column firmly planted in earth. It is worth considering whether this rootedness is revealed through words spoken by the figure, or through the way in which Napoleon sees reality. At first it may seem that the figures of both rulers are balanced by being equipped with both "spiritual" volatility (an obvious feature of the dead who appear in the dialogue, as is also confirmed by the later mention that "both are shrouded in the same blue of immortality") and the "weight of bronze." At this point one can also ask how this characteristic is realized in the case of Julius Caesar. This is why this passage should be understood differently than by assuming that each of these properties belongs

the element of earth in the poem is the column, which makes it possible - by slightly reducing the "heavenliness" of the vision - to confront this otherworldly conversation with an urban imaginary. Monuments, buildings and columns come alive when the citizens are asleep. In the first part of Hugo's ode to the Vendôme Column we learn how the poet would often face it in under special circumstances: on evenings when the night makes the moon turn away and shakes the sky with all its stars: "Que de fois, tu le sais, quand la nuit sous ses voiles / Fait fuir la blanche lune ou trembler les étoiles" (V. HuGO, "À la colonne," ibid., p. 335). Although metaphorical, the moon disappears in Norwid's poem at the very beginning, rising at the end. Perhaps it is also a symbol of another reality, where the meeting could take place.

${ }^{17}$ Kadyjewska argues that the apparition of Caesar "seems to rise to the top of the column like a cloud, hiding at the same time from the unwanted eyes of observers below" ("Norwidowskie rozmowy umarłych," pp. 280-281). In my view, Caesar rather moves from top to bottom, as indicated by the comparison with a cloud, which goes under the moon ("popod"). Inspired by the French dialogue of the columns (F. LEBcEuf, Dialogue entre la colonne Vendôme et la colonne de Juillet, Paris 1843), I decided to check whether it would be possible to stage such a conversation. In the nineteenth century, Parisians could admire two monuments to Julius Caesar, both in Jardin des Tuileries: one by Nicolas Coustou (unveiled in 1722, after the completion of the Louvre) and the other by Ambrogio Parisi (unveiled in 1800, a copy of the monument is located in the Louvre). Conversations between monuments are also represented in French poetry by Theophile Gautier's Nostalgies d'obélisques, which is discussed in the context of Norwid by Maciej Żurowski in Między renesansem i awangarda. O literaturze europejskiej z perspektywy komparatysty, Warszawa 2007, pp. 157-158. 
to both figures: it is Julius Caesar who displays the "volatility of the spirit," while Napoleon has the "weight of bronze"; however, they are "in agreement" because thanks to these features they can enter conversation. Anticipating the analysis of the subjects they address, one should emphasise that Napoleon refers to primary human needs such as the need to eat: "Godziny jednej nie przeżyłeś w głodzie" [You have not lived a single hour in hunger], he says in reference to the sense of a lack of fulfilment ("w ducha pragnieniu" [in the desire of the spirit]), sharing war experiences that interfere with one's body ("Nie czułeś mieczy, gdy się krwią wilgocą" [You have not felt swords wetting with blood]).

In this context, the word "moc" [power] appears for the first time in Napoleon's confession. He insists that he understands it not only in the normal sense, but also in terms of being incarnated, transformed "na stal i fortel, i na spiż" [into steel and stratagem, and into bronze]. As Napoleon notes, although Julius Caesar reigned in the first century $\mathrm{BC}$, he is "młodszy mocą czasów" [younger with the power of times] than the Saviour. Power can thus become the attribute of both the epoch and its heroes. The instance responsible for distributing power is God, which is symbolically represented in the image of a storm, where power returns "thunderous," manifesting in the "split" sky, which can be read as a biblical way of understanding the wrath of God (Genesis 1: 18). The word "moc" recurs again in a question that begins with a sigh: "- Ach, moc!... o cieniu!... a nieba odbicie / W sumieniu?!" [Oh, power!... O, shadow! ... and what about the reflection of heaven / In conscience?! ]

The second key term that suggests itself irresistibly to Napoleon in his speech is the epithet "triumfalny" [triumphal], whose significance is underlined at the beginning of this article in reference to the column. It appears three times in "Vendôme," but only once in connection with the column, although other instances refer to the symbolism of emperors who have ruled ancient Rome:

[...] Człowiek coraz więcej dziécię,

Aż uniemowli się w apoteozie

Na triumfalnym do Królestwa wozie. [...]

A tryumfalną kto raz przeszedł bramą

I słodki poczuł cień architektury,

Ten... ale komuż kazać mam o sile

Triumfalnymi mierzonej kolumny?... ${ }^{18}$

[People are ever more like children,

Until they infantilize themselves in apotheosis

On a triumphal chariot headed to Heaven. [...]

${ }^{18}$ C. Norwid, Vendôme, PWsz I, 110. 
Whoever crossed the triumphal arch once

And felt the sweet shadow of its architecture,

They... but who can I preach to about the power

of the column measured in triumphs?...]

The chariot, "brama" [gate] (or arch) and columns - among these three elements only two are used in the expected context, i.e. in descriptions of satisfaction derived from reigning, expanding, and gaining power over people who erect monuments to extol the emperor. However, some aspects are surprising - the triumphal chariot is used as a tool that helps one reach the Kingdom. Every human being must become infantilized ["uniemowli się"] when crossing the Gates of Heaven, but the magician (sculptor) also "silences" the great figures, "olbrzymów ziemi" [the giants of earth] who become "nieba dziecięciem" [the children of heavens], including ones whose columns elevated them as triumphers. The above indication that power can be the attribute of both an epoch and its figures, I have relied on Norwid's claim that: "Otóż i z mocą stawa się tak samo, / Jako z mężami, z brązy i z marmury" [And so the same thing happens with power / As with statesmen, with bronze and marble].

Power is the strength of the world's nations that Napoleon mentions ("I one m ocy tak się rozmocniły" [And those powers empowered themselves so much]). Napoleon proved that he understood the significance of power, but he also confesses that reaching it to the degree defined by the people is not his goal because he understands the limits of "wszech-siła" [omni-power] in the human sense. After defeat, another triumpher emerges, just like the apogee of Napoleon's power came after the epoch of Julius Caesar (who suggest to his interlocutor: "ile twe ja byłem dziecię"19 [if yours I have been a child]), battlefield again becomes battlefield, while "z człeka się wywalcza człowiek" [man emerges in fight with man]. The architectural element of the triumphal arch returns towards the end of the vision, doubled and multiplied as the beginning and end ("od łuku bliżej dziś do łuku" [the distance between arches is smaller today]), and finally appearing as a symbol of universality ("wszech-łuk" [omni-arch]). The conclusion also brings the last use of the epithet "triumfalny" [triumphal] in the phrase "sny przetriumfalne" [hyper-triumphal dreams].

The vertical movement introduced early into the lyrical imagery of the poem "Vendôme" returns after a pause that occurs after the dialogue ceases, enriched with a horizontal dimension:

${ }^{19}$ The parallel between the actions of Julius Caesar and Napoleon, recognized in the Polish Romantic tradition, is also revealed in Hugo's ode "À la colonne": "Ah !... comme ce Romain qui remuait la terre, / Vous portez, ô Français ! et la paix et la guerre / Dans le pli de votre manteaux" (p. 333). 
Tu się chmurami zakrył szczyt kolumny

A bokiem księżyc występował młody

Jako atłasu brzeg z zamkniętej trumny

I była cichość bardzo przepaścista.

Od ziemi lekki tuman mgły powstawał,

Od niebios gwiazda czasem spadła czysta,

I jakby czyn się gdzieś uroczy stawał,

Dobrotliwiało natury oblicze. ${ }^{20}$

[The top of the column covered itself with clouds

While the young moon appeared at the side

Like a satin edge in a closed coffin

And there was vast silence.

A light cloud of mist rose from the ground,

A pure star sometimes felt from the sky,

And the face of nature became kind-hearted,

As if a noble deed was done somewhere. - ]

The column disappears from the readers' view as if it were an illustrated page that is being folded from the sides, clouds appearing from one direction and the moon from another, a mist arriving from the bottom ("od ziemi" [from the ground]) and the last line designating the trajectory of a star falling from above ("od niebios" [from the sky]). Thus, the comparison with a closed coffin should not be surprising because the column is in fact enclosed by natural and cosmic phenomena. Similarly, it may not be astonishing to read about the countenance of nature, although the conversation between Napoleon and Caesar took place, as we learn at the beginning, in a busy city ("mieście gwarnym"). I am not entirely convinced by the interpretation of this scene proposed by Zygmunt Dokurno, who argues that "ordinary, everyday nature covers historical deeds, itself remaining unchanged" and concludes that "the achievements of even the greatest people fade in the face of nature." ${ }^{21}$ Instead, I would go along with the hypothesis formulated by Anna Kadyjewska, who claims that "after the conversation at the top of the column, certain changes occur in nature," signalled in this passage by the last line ("Dobrotliwiało natury oblicze" [the face of nature became kind-hearted]) and the comparison "jakby czyn się gdzieś uroc-

${ }^{20}$ C. Norwid, Vendôme, PWsz I, 112.

${ }^{21}$ Z. DokURno, Przyroda w lirykach Norwida, "Zeszyty Naukowe UMK: Nauki humanistyczno-społeczne" 1957, vol. 2, pp. 133-134.

22 A. KADYJEWSKA, Norwidowskie rozmowy umartych, p. 291. 
zy stawał" [as if a noble deed was done somewhere]. However, this theme is fully articulated only in the following phrases from the poem's conclusion: "Więc nikło jedno - drugie się nieciło" [And so one faded as the other kindled] and "Cały się rzeczy rytm przelewał w inny" [The entire rhythm of things shifted]. It is worth noting that suggestions of anticipated change are already present in some of the preceding passages that speak of "rozłagodzenie" [a soothing], which indeed may not herald sudden and spectacular change like "blask" [blaze] or "promień" [ray], but suggest the kind of transformation that would be like "życia drugiego poczęcie" [the beginning of a second life]. The Vendôme Column carri, along with itself, the hero of earthly fame, who expresses power. In the changed world the bronze of deeds remains - or has become yet again - bronze, while te value of "power" has been diminished because it appears to be limited, which contradicts the idea of the eternal Rome and the infinite glory of its heroes. According to Maria Janion, this means that in Norwid's world "the power of maturing nations is rising, as does the moral responsibility of each individual. [...] Monuments commemorating the fame of former kings will fade, and peoples will make the effort to liberate themselves through power and work." ${ }^{23}$ Nevertheless, this perspective lacks one key element that was identified by Lyszczyna: "both already know that the principle of history consists in the transmutation of pagan power into "childlike' Christian weakness - into silence and the triumph of conscience. ${ }^{24}$ It thus remains to establish where the column ends and where it finds that which it seeks. The ending of Vendôme suggests that one cannot obtain answers to these questions: the top of the column, just like the entire structure itself, has been obscured by a natural spectacle, making it impossible to discern the thread on which Julius Caesar hangs, or find its beginning.

Kadyjewska points out the ambiguity of the poem's ending, posing questions about the pessimism that is possibly suggested by "czczość" [futility]. One potential answer would be to argue that nature, playing its last chord, confirms the truth expressed by Napoleon, convincing not only his diligent student (who was listening to this nocturnal lecture on history) but also the readers of the poem. The conclusion would be thus closest to the conclusion drawn by Kadyjewska with regard to "the two worlds coming closer, establishing communication between earth and heaven." ${ }^{25}$ Alicja Lisiecka indicates the "moral and reformist" character of the category of deed in Norwid's views from the $1840 \mathrm{~s}$ and $1850 \mathrm{~s} .{ }^{26}$ One

${ }^{23}$ M. JANION, M. ŻMigRodZKa, Romantyzm i historia, Warszawa 1978, p. 243.

24 J. Lyszczyna, Dumanie na placu Vendôme, p. 308.

25 A. KADYJEWSKa, Norwidowskie rozmowy umarlych, p. 291.

${ }^{26}$ A. Lisiecka, Z problemów historyzmu Cypriana Norwida: na marginesie tomu 7 'Pism', 
such postulated deed, announced by an aura of lightness and gentleness that surrounds nature, would be "przepalenie globu sumieniem" [burning the globe with conscience]. Conscience appears here to be a vehicle of the heaven's reflection ("odbicia nieba"). It should seize the earth, which in fact desires such change, as symbolized by hands lifted high ("ręce [...] niezamykalne, / Najokropniejszą rozpadke tęsknotą" [hands [...] impossible to close, / Broken with the worst longing]).

If we understand futility in the way suggested by a later passage from Epimenides ("Zbłąkanych kolumn wiele gmachu gdzieś szukało - / I czczo było: czas mijał, pył padał - cóż życie?” [Many lost columns were looking for an edifice - / It was vain: time flew, dust fell - what of life?]), it would be difficult to establish a different dimension of the ending than a nihilistic one. The sailing metaphor from the conclusion of the poem "Vendôme" is constructed around the image of sails and the sound of deckhands signing, but it does not have to be reduced to aquatic symbolism ("kapania na przelewie" [dripping at the overflow]) because it is in fact a sea image, where the strength of wind plays an important role. "Czczośćc" can be also understood as lack of air, or vacuum. Such use of the word "czczy" was not alien to Norwid, as confirmed in Cywilizacja [Civilization]: "wbiegłem pomiędzy ramiona dwóch żandarmów, którzy odpłynięcia statku strzegli, jako kariatydy dwie czczość powietrza podpierające [...]." ${ }^{, 7}$ [I ran into the arms of two gendarmes who prevented the ship from leaving, like two caryatids suspending empty air] Gusts of wind serve the sailors because they fill the sails, and although they sometimes fall silent (or "futile"), they may blow briskly later. Both the theme of the mast and the aforementioned caryatides perfectly match the proposed interpretation of the column as a construction that lifts itself. On the light of Victor Hugo's observation that "more greatness entails more nothingness" ${ }^{28}$ - made in the context of Napoleon, Caesar, Muhammad, and Pericles $^{29}$ - one can realize that eternal glory is not won by those standing atop the triumphal columns because such monuments can easily turn into dust, which is confirmed by histories of monuments erected around the world to commemorate ancient and modern leaders, including Napoleon, but by those who have approximated "Przedwieczny" [the pre-eternal] through physical death: "Zawsze

\footnotetext{
“Pamiętnik Literacki” 50 (1959), no. 2, pp. 369-370.

27 C. Norwid, Cywilizacja, PWsz VI, 48.

28 V. Hugo, Les Feuilles d'automne, IV, [in:] IDEM, Euvres complètes. Poésie, vol. 2, Paris 1837, p. 487: "Hélas! plus de grandeur contient plus de néant! / La bombe atteint plutôt l'obélisque géant / Que la tourelle des colombes."

29 Ibid.: "Napoléon, César, Mahomet, Périclès, / Rien qui ne tombe et ne s'efface!"
} 
w śmierci się imię Bóg do królów zbliża"30 [In death, the name of God always comes close to kings]. Although futility may be close to nothingness, it can save those values that are destined to last forever and not to dazzle onlookers with the sheer weight of bronze.

Categories of the deed and the good that begins to dominate the landscape when the deed is done are considered in Norwid's "third" letter about emigration written that year: "Szanuję też wszystko nieobłudnie, co ofierniczego, tajemnego w boleściach się Polski zanieciło. Ale byłoby brakiem wiary w naród - ale byłoby patriotyzmem chorobliwym nie orzec otwarcie, iż tych rzeczy do codziennych kwestii się nie mięsza, ale się z nimi łączy tylko, i to przez dobrego uczynienie" [I also respect, without falsehood, all the sacrificial and mysterious embers flickering in the pains of Poland. However, it would demonstrate lack of faith in the nation and sickly patriotism to avoid saying that such things should not be mixed with everyday matters for they become connected only through good deeds]. ${ }^{31}$

\section{SCENE TWO. "RZYM, PAN NA ZIEMI, KONA I SZALEJE" [ROME, RULER OF EARTH, IS DYING AND BECOMING INSANE]}

In the poem Vendome it is people who embody the process of continuing historical deeds through the dialogue of two people expressing two epochs - the conversation between Caesar and his spiritual son. In Odpowiedź do Włoch, on the other hand, this continuity is symbolized by matter: the column in Place Vendôme comes from ancient Rome but had been "trans-bronzed" ("przebrązowana") to point to another ruler - Napoleon. The multiplicity of architectural elements alluding to classical notions and developing the space of Vendome is replaced here with a range of figures communicating the parallel between ancient Rome and nineteenth-century Paris: Irydion and Masinissa, the praetorians and the judged Jesus, as well as the Slavic man. As Piotr Chlebowski notes, "the poem gravitates toward maximum condensation; themes and symbols are like colourful blots thrown by the artist onto an empty canvas, while their barely noticeable outlines allow one only to approximate and guess when attempting to describe them in detail. ${ }^{\prime 32}$ Readers may try to understand the poem primarily by adding verbs to the text because they have been scantily placed in certain passages: in the question

\footnotetext{
${ }^{30}$ Ibid.: "C'est toujours par la mort que Dieu s'unit aux rois; [...]."

31 PWsz VII, 24.

32 P. Chlebowski, Odpowiedź do Włoch... (Fraszka), [in:] Norwidowskie fraszki (?), ed. J.
} Leociak, Warszawa 1996, pp. 130-131. 
posed in the second stanza, in the subordinate sentence (an adverbial of cause) in the third stanza, and in the last sentence of the poem in the fourth stanza. Thus, many themes are in fact left to themselves here, including that of the column:

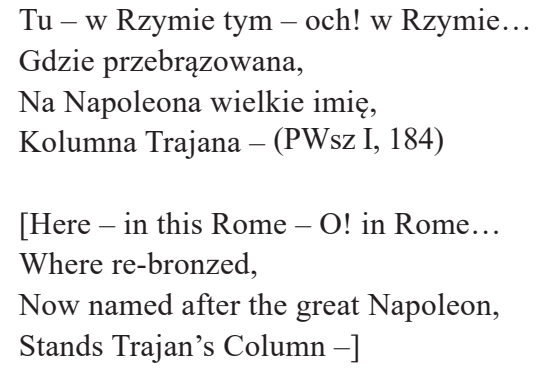

The Roman column rises, stands, delights, and perhaps simply is. Listed among several objects in the first stanza (alongside sword, armour, and catacombs) and set in the classical context, it does not require verbum as much as is the case at the beginning of the second page, where lack of verb contributes to the ambiguity of the passage:

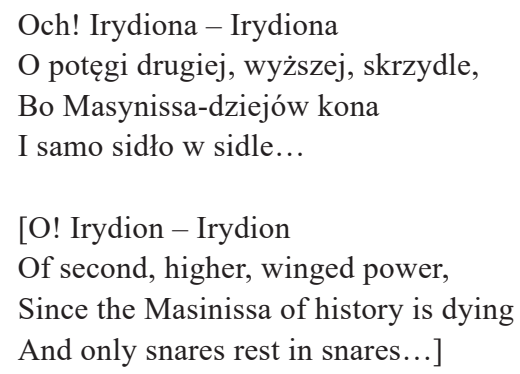

Chlebowski discerns a "calling" ${ }^{33}$ here, indicating that there is need for someone else than the one whose attribute is a "short sword." Grażyna HalkiewiczSojak reads this passage differently, demonstrating that the third stanza continues the eventfulness of the second: “'Że zwyciężyłeś, Panie... [That you prevailed, O Lord]' finds a syntactical complement in the third stanza: '[you defeated] Irydiona' and '[you won] Bo Massynisa-dziejów kona [Because the Masinissa of history is dying].'",34

\footnotetext{
33 P. Chlebowski, Odpowiedź do Włoch ... (Fraszka), p. 129.

34 G. Halkiewicz-SoJAK, “[Wokół interpretacji],” [in:] Norwidowskie fraszki (?), p. 139.
} 
A footnote accompanies the mention of the column in Norwid's poem - one of the two that begin with the word "wiadomo" [surely]. Mention of the name "Trajan's column" in the text as well as the fact that it evokes Napoleon emphasise the objective character of this remark - the column would not be a "resemblance" or "appearance" but a copy and was in fact intended as such, which is confirmed by reports from various stages of its design and construction. ${ }^{35}$ This hypothesis gains credence if we also consider the second footnote. At the origin of the desire to clarify there cannot be merely the fact that the poem underscores the architectural kinship between the Vendôme Column and that of Trajan if the very same sentence indicates another one - that of Antonius. It may be the case that the reference to the very fact of drawing from the Roman tradition of honouring leaders is of greater importance here. ${ }^{36}$ Another reason why Norwid decided to write a footnote could be that he wanted to emphasise that the column is a copy, which dovetails with the conclusions of Halkiewicz-Sojak regarding the epithet "przebrązowana," which she sees as "bringing associations with analogous structures in word formation: przepisana, przerysowana, przenicowana... [rewritten, redrawn, reconsidered]. In one word it captures the derivativeness and the false splendour of the Caesarean aspirations in mid-nineteenth-century Paris. ${ }^{, 37}$ However, the intention of the architects was to emphasise that the First Empire was superior to Caesarean Rome by introducing the idea with certain modifications. ${ }^{38}$

35 D. Rowell, Paris: The "New Rome" of Napoleon I, pp. 68-69: "Most recommendations opt for a triumphal structure reminiscent of Trajan's Column: one such proposal envisages an exact copy, with the addition of certain modifications enduring absolutely that the glorious actions of Napoleon, rather than those of Trajan, be the focus of the monument and its decoration! Although the Colonne de la Grande Armée [...] differed slightly to the earlier proposal [...], the monument's relationship with Trajan's Column was certainly no less explicit. The architects of this splendid Napoleonic structure [...] worked under the direction of Denon. While the Emperor was also directly involved in the project, Denon played a salient role, especially in relation to the finished structure's affinity with Trajan's Column."

${ }^{36}$ In the case of both columns the top is occupied not by emperors but by saints: "If we allow [...] our sight to wander farther, beyond the Capitol and the narrow streets of today's Rome, two bronze figures of apostles rise far above the temple tops, standing on pagan columns: Saint Paul wielding a sword as the earth's conqueror atop a column that once hosted the monument of Marcus Aurelius, and Saint Peter holding keys, the conqueror of Heaven, standing on a column that used to lift Trajan. These two columns tellingly depict Christianity's attitude to Roman history, which it conquered, but was aided in this by basing on the power of the state built by the likes of Trajan and Marcus Aurelius" (K. ChŁ̨̨Dowski, Szkice z Włoch, "Przegląd Polski” 8, vol. 1, July 1873, p. 37).

${ }^{37}$ G. HalKIEWICZ-SOJAK, "[Wokół interpretacji],” p. 141.

${ }^{38}$ The Vendôme Column was higher, representing contemporary events and reproducing their realities. See: D. Rowell, Paris: The "New Rome" of Napoleon I, pp. 70-71. 
On the basis of the text alone it remains impossible to answer the initial question about what the column seeks, although it carries the name of the one who is preparing a coup d'état. The desire for "potęga druga, wyższa" [the second, higher power] and "moc druga, młodzieńcza" 39 [the second power, one of youth] nevertheless makes this poem seem to attempt to connect these values with the image of the triumphal column. Conclusions seem to be identical with ones already drawn with regard to the understanding of power, which must rise to other values than only "external trappings of strength that conceal actual weakness, creative impotence and internal decay of culture." ${ }^{" 40}$ Edward Kasperski indicates the concurrence of conclusions drawn from this poem and from the fourth lecture on Słowacki with regard to "archistrategia dziejów"41 [the arch-strategy of history]; further, it is worth mentioning that in a discussion of "drugiej potęgi osie" [axis of the second power] Norwid notes that in France they are constituted by "własne rewolucje" [their own revolutions].

In the sketch Obywatel Gustaw Courbet [Citizen Gustaw Courbet], written in 1872 after the Vendôme Column was demolished during the Paris Commune, Nowid noted that "the Federation of Parisian artists was formed out of the revolution on 18 March. The Vendôme Column shattered against the ground in the square on 16 May." ${ }^{43}$ Two events contributed to the process of "dojrzewanie na słońcu" [maturing in the sun] of "arcywielkiego jakiego skandalu" [some archgrand scandal], which revealed "zatracenie duszy człowieczej" [the perdition of the human soul] and "cywilizacji rezultatu!" [the result of civilization!] comprising high praise voiced by some critics, which would not correspond to the actual message of Courbet's works. The fall of the column thus defines the end of a certain chapter in the life of this artist. ${ }^{44}$ Still, Paris emerges from Norwid's sketch as a city shaken by historical changes, or a veteran of reconstructions, as confirmed by the image of a "great city haunted by a lust for barricades yet capable of lifting itself from destruction with equal passion."

${ }^{39}$ Cf. P. Chlebowski, Odpowiedź do Włoch... (Fraszka), p. 131.

${ }^{40}$ Ibid., p. 125.

${ }^{41}$ E. KASPERSKI, Dyskursy romantyków. Norwid i inni, Warszawa 2003, p. 133.

${ }^{42}$ C. Norwid, O Juliuszu Stowackim, PWsz VI, 436.

${ }^{43}$ IDEM, Obywatel Gustaw Courbet, PWsz VI, 491.

${ }^{44}$ The scandal that Norwid discusses refers to an event linked with the Vendôme Column. Courbet became a member of the Commune's council on 16 April 1871, whereas the order to destroy the column was issued already on 12 April. The fact that Courbet countersigned it and was present on-site when the order was realized, as well as other circumstances and comments contributed to finding him guilty, which resulted in a fine and made Courbet spend the rest of his life in exile.

45 C. Norwid, Obywatel Gustaw Courbet, PWsz VI, 485. 


\section{SCENE THREE. INSTEAD OF LOURDES, ROME, PARIS - PARIS, ROME, PAESTUM}

Among Norwid's discussed testimonies of the legendary French Emperor the text that comes closest to the emotional ode by Victor Hugo dedicated to the Vendôme Column is a quatrain from the long poem Szczesna. Hugo's piece was first published on 9 February 1827 in "Journal des Débats" as a response to an event that occurred in January of the same year in the Austrian embassy in Paris. Four invited marshals were announced without titles given to them by Napoleon. ${ }^{46}$ The ode is valued as an intimate confession in which Hugo goes into raptures worshipping Napoleon and develops a historical message represented by the column itself. ${ }^{47}$ The poet calls this monument a "triumphal ruin" (the epithet that belongs with the column intriguingly accompanies "ruins" here, which can signal transience and fall) and argues that no foreigner ever walked in the shadow of the column without shuddering in fear. To quote the epistolary report by Szczesny, a Polish man in Paris:

\footnotetext{
"Paryż, kolumna Vendôme - data - stałem,

Patrząc... brąz czynów gdy w powietrzu trzyma,

Tez, anty-tez nie pytaj - wyznam, że zadrżałem ${ }^{48}$

Jak dziecię na podniosłym ramieniu olbrzyma [...]"49

[Paris, the Vendôme Column - date - I stood

Looking... the bronze of deeds standing in the air,

Do not ask about theses and anti-theses - I confess I trembled

Like a child at the high shoulders of a giant]
}

46 J. Cousin, Napoléon Ier dans l'œuvre de Victor Hugo avant l'exil, [in:] Mélanges de littérature, philologie et histoire offerts à Louis Arnould, Genève 1973, p. 122.

47 A. Lavernhe-Grosset, 'Cela vaudra-t-il la peine d'être lu ? Cela sera-t-il lu ?', [in:] Envois et dédicaces, ed. G. Farasse, Villeneuve d'Ascq 2010, p. 102: "L'intensité du manque et la voracité de cette lecture attachent la mémoire dépossédée du poète au déroulement imaginaire des bas-reliefs, comme une bouche avide aspire à se remplir. [...] Les yeux éblouis par la colonne en mouvement, le poète réveille la Grande Armée [...]."

${ }^{48}$ Cf. V. Hugo, À la colonne, p. 334: "l'étranger t'admire avec effroi; Jamais, ô monument, [...] Les étrangers sans peur n'ont passé sous ton ombre."

${ }^{49}$ C. Norwid, Szczesna, DW III, 75. Cf. V. Hugo, À la colonne, p. 333: “[...] de tout ce qu'a fait une main colossale, / Seul es resté debout; — ruine triomphale / De l'édifice du géant!" 
Meeting the Paris column is a different kind of experience for Szczesny than that which he had earlier in Germany ("chodzę na kursa filozofii" [I attend a philosophy course]) and would have later in Rome, where the analogy to Paris could be achieved by replacing "stałem, patrząc" [I stood looking] with "ukląkłem, modląc się" [I kneeled, praying]:

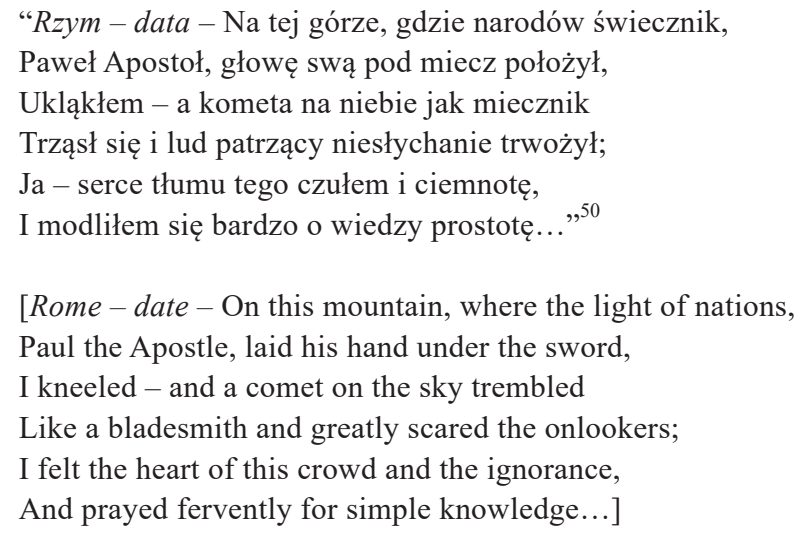

Unlike in other writings by Norwid, the above passages (two subsequent stanzas) do not draw a parallel between the images of the two cities in an attempt to unify them or emphasise continuity between Roman and French heritage. They rather constitute descriptions of two events occurring one after another, temporally and spatially, which accentuates the multiplicity of the protagonist's experiences. Nevertheless, both in terms of form (epistolographic stylization in the form of an unconventional letter head, with place and postage date) and imagery (comparisons "jak dziecię" and "jak miecznik") it is possible to find justification for comparing these two urbanist reflections and seeking equivalence with regard to their motifs. Embarking on this kind of experiment, one can suggest that what emerges in the excerpt from the Parisian letter is an upward movement, while a downward one appears in Roman reflections. The protagonist is standing before the Vendôme Column and admiring it, which requires looking up (given the forty-four meters of height). In the case of Roman experiences, on the other hand, what draws the attention of those looking is the comet, but importantly we cannot be certain whether the protagonist is among the gathered - it is the people who gaze, but Szczesny may have bowed his head in prayer-like reflection. The sense that helps him to unite with those admiring the cosmic spectacle is the heart, which means that he rather empathises with others rather than sees the same thing.

${ }^{50}$ C. NorwID, Szczesna, DW III, 75. 
Another example marked by antinomy and contained in the discussed two stanzas is a certain kind of gesture that is described in the second line of both stanzas: in Paris the column holds ("trzyma") the bronze of deeds in the air, while in Rome "Paweł apostoł, głowę swą pod miecz położył" [Paul the Apostle, laid his head under the sword]. The verbs "trzymać" and "położyć" emphasise differences between the action reified by the Parisian column and the martyrdom of Paul the Apostle, between the singularity of deed, its achievement, and imperfective lasting. Introduction of the category of the deed expands Norwid's repertoire of thoughts connected with the triumphal column, as is already suggested by the words about good deeds: it is not only power and might but also the record ("zapis") of deeds on the arena of history that find their expression through the column. The word "record" is not accidental here. Just like the mediaeval epic poems called chansons de geste would extol the battle tumult of Charlemagne's empire, the spiralling bas reliefs on classical Roman columns would tell the stories of the emperors' conquests (res gestae). However, there is also another possibility to interpret the passage devoted to Rome, following the additional remark about the Roman hill placed right after the date in the Italian letter - perhaps it should not be treated as the equivalent of the group "brąz czynów" [the bronze of deeds] but of the phrase "kolumna Vendôme" [the Vendôme Column] as a specification of place (apparently missing): after all, there is "Paryż, kolumna Vendôme, data" [Paris, the Vendôme Column, date] but only "Rzym - data" [Rome-date]. In this case, the periphrasis "brąz czynów" would correspond to the image of Roman comet (which brings this passage closer to the poem "Vendôme," where the sight of the column is accompanied by falling stars). One more important element is the comparison "Jak dziecię na podniosłym ramieniu olbrzyma" [Like a child at the high shoulders of a giant], which in turn indicates a different position of the looking person than in the poem Vendôme, which mentions "śmiertelny, co pogląda z ziemi" [the mortal looking from below]. However, whereas in the case of this poem we may be considering the figure of a lazy stroller in Paris, the reference to Bernard of Chartres ${ }^{51}$ in the long poem Szczesna indicates that this enunciation may be the voice of modern generations.

It is also worth adding that the poem also contains a hint that undermines my hypothesis regarding the different directions of movement in these two passages: "na tej górze, gdzie narodów świecznik" [on this mountain, where the light of nations]. In the novel Corinne; or Italy by Anne-Louise Germaine de Staël - one of the works that shaped the image of Italy during Romanticism - Rome appears

${ }^{51}$ S. Wielgus, Z badań nad średniowieczem, Lublin 1995, p. 13: "We are dwarves who have climbed the shoulders of giants. We can therefore see more and farther, but not because our eyes are better, or our height bigger, but because they have lifted us above and hold at a giant's height." 
to be a place created from a different matter than other earthly cities thanks to the presence of columns and towers:

Around, and on the Seven Hills, are seen a multitude of spires and obelisks, the columns of Trajan and of Antoninus, the tower of Conti, whence, it is said, Nero overlooked the conflagration of Rome, and the dome of St. Peter's lording it over the highest. The air seems peopled by these heaven-aspiring fanes, as if an aerial city soared majestic above that of the earth. ${ }^{52}$

After the German course in philosophy it is only in Paris that Szczesny realizes that the questions he had posed were inappropriate: "Tez, anty-tez nie pytaj" ${ }^{53}$ [Do not ask about theses and anti-theses]. In Rome he begins to desire the "simplicity of knowledge" that could be described using the following passage from Quidam:

\section{[...] - Lud jest zawsze może}

Na równi z wiedza, chociaż jej nie sprosta

Wypowiedzeniem, ni pojąć jej może,

Lecz drgnieniem serca jednym wie, co ludzie

W umiejętności otrzymują trudzie. ${ }^{54}$

As is underscored by Magdalena Woźniewska-Działak, it is only in Rome that the "truly initiatory character" of Szczesny's journey is revealed. ${ }^{55}$ In light of this interpretation, the images of Rome and Paris from Szczesna may appear different than in Odpowiedź do Włoch, where - as Magdalena Karamucka notes - "[i]n the context of the entire work, the civilization of reason ascribed to Rome, continued, according to Norwid, among other places in nineteenth-century Paris, is clearly subjected to criticism. ${ }^{" 56}$ What appears clear here is the differentiation between physical might and rational understanding, the former surpassed by the latter alongside the wisdom of the heart, which instinctively grasps historical truths.

Continuing his journey to Italy, Szczesny visits Paestum, whose description does not feature any columns, despite clear mention of three temples preserved

${ }^{52}$ G. DE StaËL-Holstein, Corinne; or, Italy, trans. I. Hill, London 1833, Chapter V. Online: http://www.gutenberg.org/files/52077/52077-h/52077-h.htm (accessed 20 January 2021).

${ }^{53}$ Further context is offered by the "third" letter on emigration: "German philosophy, which was led in its critical autocracy to arrange the past logically, concluding where it stopped, inclining only to close the book, says: 'Yes - indeed - it was necessary and so it necessarily happened',"' PWsz VII, 25.

${ }^{54}$ C. NorwID, Szczesna, DT III, 227.

55 M. Woźniewska-Dzialak, Poematy narracyjne Cypriana Norwida, Kraków 2014, p. 54.

${ }^{56}$ M. KARAmucKa, 'Upiorny' Rzym Norwida, [in:] Od Syberii po Ameryke. Geografia wyobrażona polskich romantyków, eds. A. Kołos, T. Ewertowski, K. Szmid, Poznań 2013, p. 52. 
there. Scholars researching this motif, however, ought to be vigilant when it comes to the account of sifting through the rubble, because a certain kind of gesture that appears in the context could be associated with the question posed at the beginning of this article, regarding what the column supports and how:
Każdy klnie, modli się, próżnuje, pości,
Lub złamki bogów z gruzów wydobytych
Na wpółżebrzącej wyciągnąwszy dłoni,
Do podróżników odzywa się sytych -
Stu pieniądz rzuca, żaden łzy nie roni!...

We may guess that fragments of these monuments ("złamki bogów" [shards of the gods]) must have been much smaller than the ones placed on the columns if they fit inside a human hand. Such a reduced monument, however, was not elevated to sit atop a triumphal column, but is brought out of oblivion by the hand of a stereotypically (i.e. negatively) represented man from southern Italy ${ }^{58}-$ the hand that lifts and provides support, so that the ancient deity can be admired by travellers in southern Italy, performs here the function of the plinth. Still, the contemplation that preoccupies the sightseers does not resemble the experience of Szczesny, who literally shuddered upon looking at the bronze of deeds in Place

${ }^{57}$ C. Norwid, Szczesna, DW III, 76.

${ }^{58}$ This may also emphasise the fact that Szczesna is more like a "social satire" than a unidirectional, ironic and self-referential "satire on a somebody's lady," as argued by Zofia Stefanowska in "Norwid a poemat dygresyjny," [in:] IDEM, Strona romantyków. Studia o Norwidzie, Lublin 1993, p. 150. I have also been drawn to the interpretation offered by Gomulicki, who reads the quoted passages from the poem in reference to the figure of Szczesna, which leads him to conclude that "the fullest characterisation of Szczesna and the most complete account of her attitude towards the lover are not shown directly, but precisely [...] in terms of 'a range of epistolary reactions' of the travelling Szczesny" (C. NoRwID, Dwa poematy milosne, ed. J.W. Gomulicki, Warszawa 1966, p. 25). According to Gomulicki, "it suffices to carefully read the quoted passages from the protagonist's letters to learn the following: from the first letter about his sadness, caused probably by the beloved; from the second one - about his becoming aware of the radical differences of character between them; and from the third - about her lack of simplicity [...]." The Berlin course in philosophy would thus constitute a response to the state of mind caused by the relationship with the beloved. The Parisian questions about thesis and antithesis would hide the secret of Szczesna's personality, while the prayer for simplicity would stem from the recognition of her shortcomings. The fifth letter from Paestum would regard, in Gomulicki's view, "the dreadful hallmarks of enslavement (in her case linked to proprieties and old conventions in general)." I would argue that in this case we deal with an excessive narrowing of the meaning of these remarks to a diagnosis of the heroine's attitude. This recognition certainly does take place in the case of Szczesny, but in passages from other letters, especially ones he begins with "Zinąd," with the place name (or rather its indefinite character) yielding before the heroine, allowing her features, gradually discovered by Szczesny, to appear on the text's semantic horizon. 
Vendôme, filled with admiration for the vastness of knowledge one can possibly learn during such a course in history, while in Paestum no one experienced any such emotion. ${ }^{59}$ The reason for this different reaction can consist in the fact that Szczesny and others differ in terms of wealth: he is certainly not "satiated" as Magdalena Woźniewska-Działak notes, while "the ruin of Paestum is primarily one that represents a degraded community, which meets, from time to time, with a satiated passer-by or stranger." ${ }^{60}$ The only reaction to the extended hand ("wpółżebrzącą" [co-begging], Norwid adds) is payment. The gesture described above finds one more application towards the end of the poem, where it regards the process of literary creativity:

Ku czemu lepszą powieść z czasem zrobię,

Morał wykażę jasno jak na dłoni,

A jaki taki grubą łzę uroni. ${ }^{61}$

[For the purpose of which I shall fashion a better story in the future,

Delivering the moral message clearly, as if in an open palm,

So that this or that person can shed a tear.]

The comparison "jak na dłoni" [as if in an open palm] refers to a gesture made by those sifting through the rubble, but readers might prove capable - Norwid seems to believe - of greater understanding than tourists confronted with the experience of disappearing traces left by ancient civilizations.

To sum up what arises from the interpretation of Szczesna, it is worth noting that the triad of Paris, Rome, and Paestum (from the north, or "northern Rome" as Edward Kasperski put it ${ }^{62}$, through Rome proper to the south) not only contains one image of a column - i.e. in Place Vendôme - but also features other gestures that I would argue copy this theme. The answer to the question posed at the outset would thus be: deed - martyr's deed / cosmic phenomenon - part of a monument rescued from ruins, which plays the function of a tourist attraction and, metaphorically, that of a moral message.

${ }^{59}$ Herbert's nineteenth-century vision of Paestum does not differ much from that of Norwid, featuring the guide, tourists, the hand gesture, and lack of emotions: "[...] tourists float about here, the guide dispassionately providing them with the temple's dimensions, precise like a bookkeeper. [...] He gestures at the altar, but no one is moved by the tossed stone" ("U Dorów," [in:] IDEM, Barbarzyńca w ogrodzie, Warszawa 2004, pp. 34-35).

${ }^{60}$ M. WoźNiewska-Dzialak, Poematy narracyjne Cypriana Norwida, p. 55.

${ }^{61}$ C. Norwid, Szczesna, DW III, 78.

${ }^{62}$ E. KASPERSKI, Dyskursy romantyków, p. 132. 


\section{CONCLUSION}

If the above analysis suggests that the question of values indicated by the Vendôme Column in confrontation with the culture of Rome has not been sufficiently illuminated than the reason for this could consist in the fact that Norwid did not really intend to make this question entirely clear. Those wishing to understand the message from the beginning of "U kolebki narodu" [At the Cradle of the Nation] have to remember that Norwid himself warned that it would not be easy to establish: "Ale zbliżenie tych dwóch rzeczy, to jest fragmentów rzeźby starożytnej, kartek Lelewela i Byrona listów, ten tylko zrozumie, kto wiedzieć by mógł, że ja inaczej pamiętnika-swojego nie pojmuję, tylko jak najciemniejszy kącik mojej pracowni!" [The coming together of these things, namely fragments of an ancient monument, pages from letters by Lelewel and Byron, can be only grasped by those who would know that I conceive my own diary only as the darkest corner of my studio!]. ${ }^{63}$ The aforementioned classical sculpture is "halfa-sculpture of Trajan's Column," while letters by Byron "written from Italy and Greece, concerning this or that, the fate of the world, of nations, of literature, and of the human heart, do so casually, with ease, almost as if by chance." Both the ancient bas-reliefs and the Byronic moods of anxious nineteenth-century wanderers have been already discerned in the above interpretation.

The Vendôme Column is set in Norwid's contemporary world - it is a nineteenth-century person that is admiring and interpreting it, but the relationship with Italy introduced by the author allows one to refer its heritage to the past. These are diverse connections - in Vendôme Paris is visited by a guest from ancient Rome, who already knows about Napoleon but nevertheless listens to his lecture; in "Odpowiedź do Włoch" the situation of Paris is described in categories known from the realities of the times when Christianity was first taking root; finally, in Szczesna the experiences of Paris, Rome and southern Italy facilitate displaying an entire gallery of human attitudes - attempts to grasp things with reason, prayers for the humbleness of heart and simplicity of knowledge, and the role of human empathy. In all of these scenes the column nevertheless offers a lesson to protagonists like Julius Caesar or Szczesny as well as to readers of Norwid (as in Odpowiedź do Włoch). This is a universal lesson regarding might, which should be transformed into spiritual power by both earthly rulers and inhabitants, helping to reign better and restore the role of empathy in human experience.

${ }^{63}$ C. NorwID, U kolebki narodu, PWsz VII, 229. 


\section{REFERENCES}

ALVEY N.M., Strange Truths in Undiscovered Lands: Shelley's Poetic Development and Romantic Geography, Toronto 2009.

BATtLeS D., The Medieval Tradition of Thebes: History and Narrative in the Roman de Thèbes, Boccaccio, Chaucer, and Lydgate, London 2004.

CHŁĘDOWSKI K., Szkice z Włoch, "Przegląd Polski" 8, vol. 1 (July 1873).

COMAY R., Mourning Sickness: Hegel and the French Revolution. Cultural Memory in the Present, Stanford 2010.

COUSIN J., Napoléon I Ir dans l'œeuvre de Victor Hugo avant l'exil, [in:] Mélanges de littérature, philologie et histoire offerts à Louis Arnould, Genève 1973.

DOKURNO Z., Przyroda w lirykach Norwida, "Zeszyty Naukowe UMK: Nauki humanistycznospołeczne" 1957, vol. 2, pp. 105-142.

HEGEL G.W.F., Esthétique: cahier de notes inédit de Victor Cousin, ed. A.P. Olivier, Paris 2005.

Hugo V., Euvres complètes. Poésie, vols. 1-2, Paris 1834-1837.

JANION M., ŻMIGRODZKA M., Romantyzm i historia, Warszawa 1978.

KADYJEWSKA A., Norwidowskie rozmowy umartych - dialog postaci i epok, [in:] Liryka Cypriana Norwida, ed. P. Chlebowski, Toruń-Lublin 2003.

KARAMUCKA M., 'Upiorny' Rzym Norwida, [in:] Od Syberii po Amerykę. Geografia wyobrażona polskich romantyków, eds. A. Kołos, T. Ewertowski, K. Szmid, Poznań 2013.

KASPERSKI E., Dyskursy romantyków. Norwid i inni, Warszawa 2003.

LABOURIEU T., La Colonne Vendôme, roman historique, Paris 1872.

LAVERnHE-GROSSET A., 'Cela vaudra-t-il la peine d'être lu ? Cela sera-t-il lu ?', [in:] Envois et dédicaces, ed. Gérard Farasse, Villeneuve d'Ascq 2010.

LEBCEUF F., Dialogue entre la colonne Vendôme et la colonne de Juillet, Paris 1843.

LISIECKA A., Z problemów historyzmu Cypriana Norwida: na marginesie tomu 7 'Pism', "Pamiętnik Literacki" 50 (1959), no. 2, pp. 331-421.

LYSZCZYNA J., Dumanie na placu Vendôme. Norwid wobec romantycznego kultu Napoleona, [in:] Norwid - spotkania kultur, ed. E. Chlebowska, Lublin 2015.

Norwidowskie fraszki (?), ed. J. Leociak, Warszawa 1996.

ROWELL D., Paris: The "New Rome" of Napoleon I, London-New York 2012.

SKILTON D., Tourists at the ruins of London. The Metropolis and the Struggle for Empire, "Cercles" 17 (2007), pp. 93-119.

STAËL-HOLSTEIN G. de, Corinne; or, Italy, trans. I. Hill, London 1833. Online: http://www.gutenberg.org/files/52077/52077-h/52077-h.htm (accessed 20 January 2021).

STEFANOWSKA Z., Norwid a poemat dygresyjny, [in:] IDEM, Strona romantyków. Studia o Norwidzie, Lublin 1993.

TROYES C. de, Cligès, Berlin 2006.

WoŹNIEWSKA-DZIAŁAK M., Poematy narracyjne Cypriana Norwida, Kraków 2014.

WYKA K., Cyprian Norwid: poeta i sztukmistrz, Kraków 1948. 


\section{SUMMARY}

The article discusses the image of a triumphal column in Norwid's poems "Vendôme," "Odpowiedź do Włoch (Fraszka)," and Szczesna. The inspiration to enquire about its function and symbolic power comes from Hegel's lectures on aesthetics and the following passage from Epimenides: "The many columns $[\ldots]$ many stray columns sought an edifice..." In Norwid's thought, eternal glory is not meant for those who stand atop a triumphal column since such monuments can easily turn into dust, as confirmed by the fate of other monuments such as those of ancient leaders and Napoleon, but for the one who comes close to the "Pre-Eternal" upon physical death. The "power" is thus a value irrevocably tied to the triumphal column but has to rise to another dimension, other than that of physical power. This article recalls the idea of Paris as the "new Rome," which was revived in the nineteenth century.

Keywords: column; Julius Caesar; Napoleon; ancient Rome; Paris; triumph; power.

MAgDalena KowalsKa holds a PhD in literary studies and is the author of books Prowansja w pismach polskich romantyków (2015) and Litanic Verse III: Francia (2018). She works at the Institute of Literary Studies at the Mikołaj Kopernik University in Toruń; e-mail: lena_k@wp.pl. 